\title{
Az extracelluláris mátrix rendellenességei epithelialis-stromalis és stromalis cornealis dystrophiákban
}

\author{
Varkoly Gréta dr. ${ }^{1}$ - Bencze János ${ }^{1}$ \\ Módis László dr. ${ }^{2^{*}}$ - Hortobágyi Tibor dr. ${ }^{1^{*}}$ \\ ${ }^{1}$ Debreceni Egyetem, Általános Orvostudományi Kar, Patológiai Intézet, Neuropatológiai Tanszék, Debrecen \\ ${ }^{2}$ Debreceni Egyetem, Klinikai Központ, Szemklinika, Debrecen
}

\begin{abstract}
A humán szaruhártya extracelluláris mátrixban gazdag. Legnagyobb részét a főként kollagénrostokból és proteoglikánokból álló, a cornea középső részén elhelyezkedő stroma teszi ki. A cornealis epithelialis-stromalis és stromalis dystrophiák a szaruhártya olyan autoszomális dominánsan vagy recesszíven öröklődő elváltozásai, amelyek kialakulásában gyulladásos, fertőző vagy traumás folyamatok nem játszanak szerepet. Az elváltozások a cornea minden rétegében megjelenhetnek, de a dystrophiák legtöbb altípusában a stroma érintett. Általában gyermekkorban vagy fiatal felnőttkorban alakulnak ki, a diagnózis viszont csak később, a tünetek megjelenésekor lehetséges (epithelialis eróziók, látáscsökkenés, fotofóbia). A cornea rétegei között lerakódó, különböző fehérjeaggregátumok (hialin, amyloid, krisztallin) a szaruhártya enyhébb vagy kifejezettebb elhomályosodását, a transzparencia részleges vagy teljes elvesztését okozzák a stromalis extracelluláris mátrix rendezettségének hiánya miatt. Mivel egyes cornealis dystrophiákban a keratán-szulfát proteoglikánok szintézise érintett, funkciójuk elvész, így nem tudják fenntartani az egyenlő interfibrillaris távolságot. Az elváltozások a progresszió során a látást nagymértékben korlátozó cornealis homályhoz vezetnek, ezért keratoplasztika válhat szükségessé. Orv. Hetil., 2016, 157(33), 1299-1303.
\end{abstract}

Kulcsszavak: cornea, cornealis dystrophia, cornealis extracelluláris mátrix

\section{Disorders of the extracellular matrix in epithelial-stromal and stromal corneal dystrophies}

The human cornea is rich in extracellular matrix. The stroma constitutes the main thickness of the cornea, which consists of collagens and proteoglycans mainly. The epithelial-stromal and stromal dystrophies of the cornea are either autosomal dominant or recessive inherited disorders, which are unrelated to inflammation or trauma. The diseases can manifest in each layer of the cornea, but in most cases the corneal stroma is affected. Generally, they develop in childhood or young adulthood but the diagnosis is only possible when clinical signs (epithelial erosions, decreased visual acuity, photophobia) develop. The different protein aggregates (hyaline, amyloid, crystalline) deposited in the corneal layers result in mild or advanced corneal opacity and loss of the corneal transparency due to disorganisation of the extracellular matrix. In some of the corneal dystrophies the keratane sulphate proteoglycan looses its function which results in a loss of the regular interfibrillar spacing. Due to the severe corneal opacity patients may need corneal transplantation.

Keywords: cornea, corneal dystrophy, corneal extracellular matrix

Varkoly, G., Brencze, J., Módis, L., Hortobágyi, T. [Disorders of the extracellular matrix in epithelial-stromal and stromal corneal dystrophies]. Orv. Hetil., 2016, 157(33), 1299-1303.

(Beérkezett: 2016. március 22.; elfogadva: 2016. május 29.)

‘Módis László és Hortobágyi Tibor egyaránt 'utolsó szerző'. 


\section{Rövidítések}

$\mathrm{BIGH} 3=\mathrm{TGF} \beta \mathrm{I}=($ transforming growth factor $\beta$ induced $)$ transzformáló növekedési faktor indukált; CHST6 = (carbohydrate-sulfotransferase 6 ) karbohidrát-szulfotranszferáz 6 E-cadherin $=$ endothelialis cadherin; E-szelektin $=$ endothelialis szelektin; $\mathrm{ECM}=$ extracellulláris mátrix; $\mathrm{GCD}=$ granularis cornealis dystrophia; IC3D $=($ International Committee for Classification of Corneal Dystropies) Nemzetközi Cornealis Dystrophia Klasszifikációs Bizottság; ICAM-1 = (intracellular adhesion molecule 1 ) intracelluláris adhéziós molekula 1 ; LCD = lattice cornealis dystrophia; $\mathrm{MCD}=$ macularis cornealis dystrophia; TGF $\beta I=$ (transforming growth factor $\beta$ induced $)$ transzformáló növekedési faktor indukált; UBIADl = (Ubi A phenyltransferase domain containing l) Ubi A feniltranszferáz domént tartalmazó gén

A cornealis dystrophiák a szaruhártya öröklött, nem gyulladásos eredetû́ elváltozásai. Pontos előfordulási arányuk meghatározatlan, de a dystrophiák minden altípusa ritka [1]. A DE-KK Szemklinikán 1946-2009 között corneatranszplantáción átesett betegek (4778 páciens) körében az esetek 6\%-ában stromalis cornealis dystrophia, 1,3\%-ában pedig endothelialis-cornealis dystrophia volt a szaruhártya-átültetés indikációja [2]. A betegség különböző gének mutációja következtében jön létre [3]. A mutációk kóros szerkezetű fehérjék termelődéséhez vezetnek (például kóros szerkezetû keratánszulfát proteoglikán) [4], amelyek oldhatatlan anyagként rakódnak le a cornea rétegein (1. ábra) belül. Általában az élet 1-2. évtizedében kezdődnek [3], de csak később, a 3-4. vagy akár a 6. évtizedben manifesztálódnak. Az elváltozás mindkét szemet érinti, a betegség progressziója során a cornea transzparenciája elvész, és a fokozódó szaruhártyahomály a látásélességet különböző mértékben korlátozza [1].

A legújabb IC3D (International Committee for Classification of Corneal Dystrophies) -klasszifikáció a cornealis dystrophiákat a depozitumok lerakódási helyének alapján négy fó kategóriába sorolja be, amelyek a következők:

1. epithelialis és subepithelialis dystrophiák;

2. epithelialis-stromalis dystrophiák;

3. stromalis dystrophiák;

4. endothelialis dystrophiák [5].

\section{Epithelialis-stromalis dystrophiák}

Epithelialis-stromalis dystrophiákban a génmutációk következtében keletkező kóros fehérjék a Bowman-membránban és a stroma elülső rétegében rakódnak le. Ebbe a kategóriába tartozó betegségek a Reis-Bücklers, ThielBehnke, lattice, valamint a granularis cornealis dystrophia I-es és II-es típusai [5]. Valamennyi altípus autoszomális domináns öröklődést mutat, az $5 \mathrm{q} 31$ kromoszómán található BIGH3 (transforming growth factor $\beta$ induced - TGFßI) gén mutációja okozza a dystrophia kialakulását. Az érintett gén az adhéziós moleku- laként szolgáló keratoepithelin fehérjét kódolja [6]. Normális körülmények között a keratoepithelin egy kisméretű fehérje, ezért a cornea rétegei között diffúzióra képes. Mutáció következtében azonban hibás keratoepithelin termelődik, a fehérje oldhatatlan lesz, így proteolitikus fragmentjeivel együtt lerakódik a szaruhártyában $[5]$.

\section{Reis-Bücklers cornealis dystrophia}

A Reis-Bücklers-dystrophia korán, 4-5 éves kor körül jelentkezik fájdalmas, visszatérő cornealis eróziók, fotofóbia [1], valamint progresszív látásromlás tüneteivel [7]. Kezdetben irreguláris, szürkésfehér opacitások alakulnak ki a Bowman-membránban és a stroma elülső részében, majd elörehaladott stádiumban a stroma mélyebb rétegeit és a limbust is érinthetik.

A subepithelialisan és a stromában lerakódó gyưrü formájú anyagok hialindepozitumok, amelyek megszakítják a Bowman-membrán folyamatosságát (2. A) ábra). A hialindepozitumok Masson-féle trikrómfestéssel piros színben túnnek fel [5].

\section{Lattice cornealis dystrophya (LCD)}

A lattice cornealis dystrophia a leggyakoribb cornealis dystrophia [5]. A Reis-Bücklers-dystrophiához hasonlóan az élet elsố évtizedében jelenik meg bilateralis látáscsökkenés, fájdalmas szaruhártya-eróziók képében [8]. Réslámpás vizsgálat során radialisan orientált, üvegszerü opacitások fedezhetők fel a stroma elülső részében. Kezdetben az úgynevezett "lattice-vonalak” (rácsrostok) a cornea centrális részén helyezkednek el, majd ahogy a betegség súlyosbodik, úgy terjed a periféria, valamint a stroma mélyebb rétegei felé [9]. Mikroszkópos vizsgálattal amyloiddepozitumok láthatók az epithelium basalis membránja és a Bowman-membrán között, illetve a stromában, amelynek köszönhetően a rendezett lamelláris szerkezet felbomlik (2. B) ábra). Az amyloiddepozitumok polarizációs mikroszkóppal vizsgálva almazöld kettős törések formájában tünnek fel (2. C) ábra). Ezenkívül epithelialis atrophia, a basalis membrán degenerációja és a Bowman-membrán elvékonyodása vagy hiánya jellemzi.

A lattice cornealis dystrophia több altípusra osztható. Bizonyos altípusai a BIGH3 gén mutációja miatt alakulnak ki (lattice cornealis dystrophia I, IIIA, I/IIIA, IV-es típusok) [5], míg a II-es típus a GSN (gelsolin) gén mutációja következtében. A gelsolin a 9. kromoszómán található gén, amely egy amyloid prekurzor proteint kódol. Ennek feladata az aktin eltávolítása a sérülés és a gyulladás helyéről. Ebben az esetben nemcsak a cornea érintett, hanem a bôr és az agyidegek is [10].

Az LCD IIIA altípusa az 5-7. évtizedben jelenik meg, vastagabb lattice-vonalak jellemzik [11], nem úgy, mint az I/IIIA típust, ahol vékony lattice-vonalak láthatók [5]. 


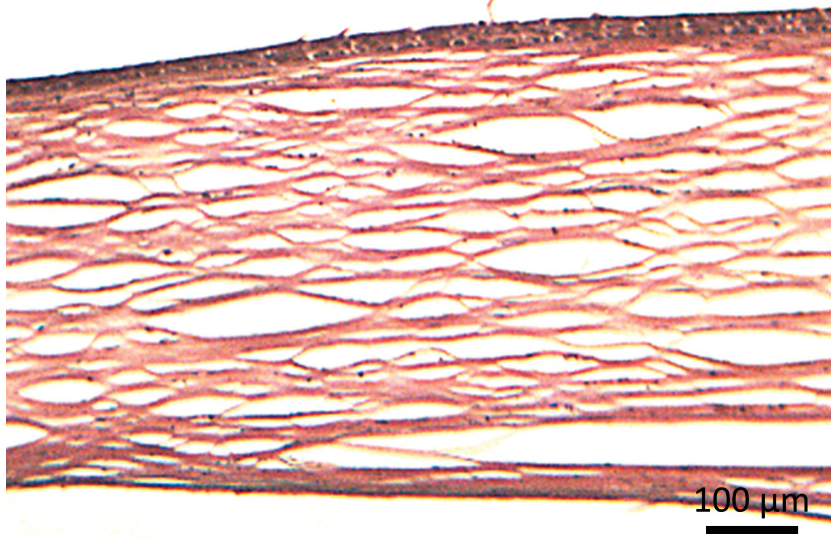

l. ábra Ép cornea (hematoxilin-eozin festés)
A IV-es típus a 7-9. évtizedben jelenik meg. Kicsiny, vékony lattice-vonalak, epithelialis eróziók és amyloiddepozitumok jellemzik [10].

\section{Granularis cornealis dystrophia, I-es tipus (GCD, Groenouw I-es tipus)}

Az élet első évtizedében jelenik meg [5] szürkésfehér morzsaszerú opacitások képében. Az opacitások a cornea centrális részén helyezkednek el, de a depozitumok között és perifériásan a szaruhártya tiszta. A többi dystrophiához hasonlóan autoszomális domináns öröklódésű, bilateralis megjelenésű [12]. A betegség kezdetben tünetmentes, később azonban az opacitások látáscsökke-
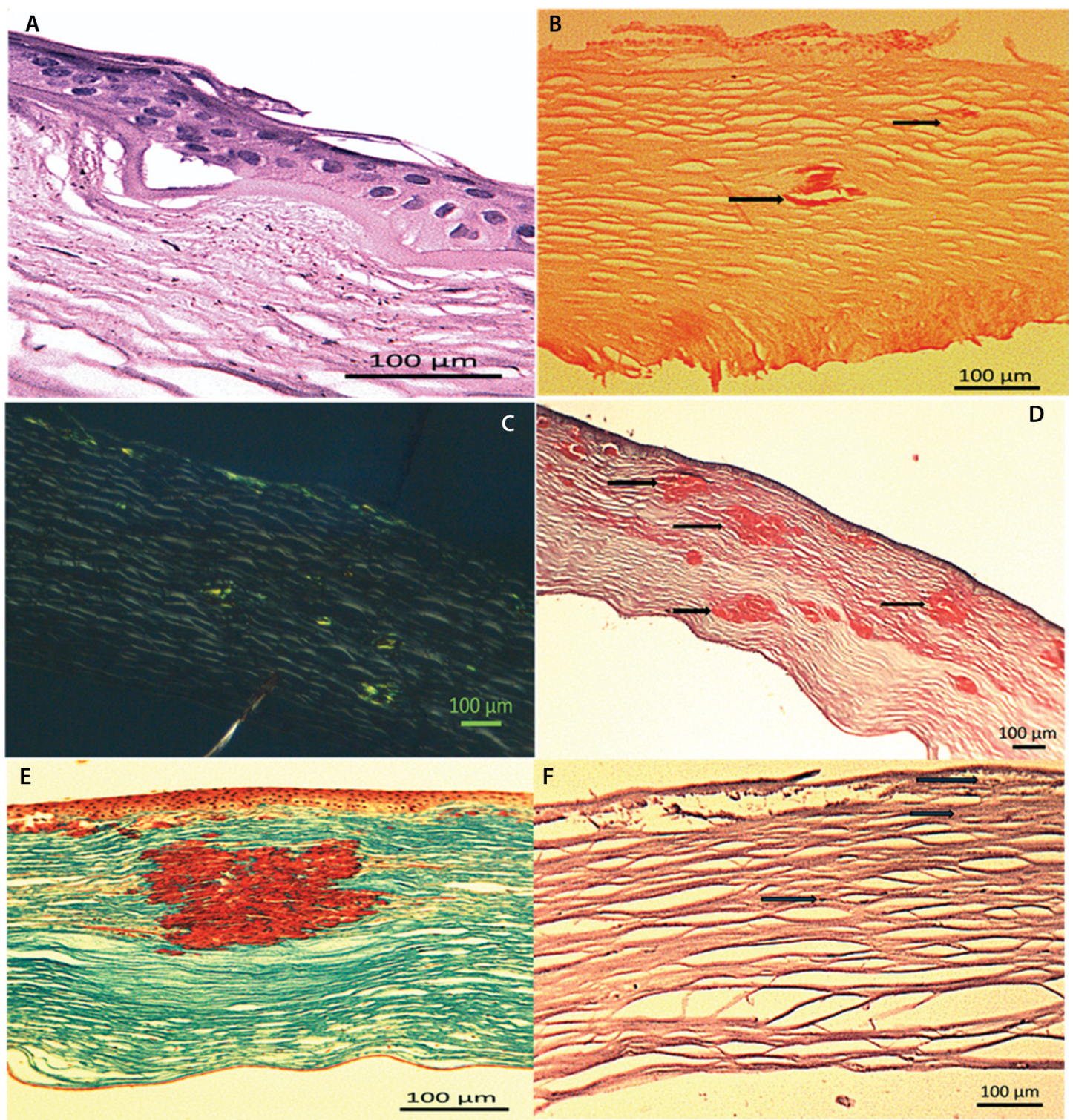

2. ábra

Cornealis dystrophiák szövettani jellemzői. A) Reis-Bücklers cornealis dystrophia; Bowman-membrán elvékonyodása látható. B) Lattice cornealis dystrophia; kongóvörös festéssel láthatók a stromában lerakódó amyloiddepozitumok (nvíl). C) Lattice cornealis dystrophia; az amyloiddepozitumok polarizációs mikroszkóppal vizsgálva almazöld kettős törést mutatnak. D) Granularis cornealis dystrophia, I-es típus; eosinophil festődést mutató hialindepozitumok a stromában (nyíl). E) Granularis cornealis dystrophia, I-es típus; Masson-féle trikrómfestéssel a hialindepozitumok vörös színúek.

F) Macularis cornealis dystrophia; PAS-sal festődő glükózaminoglikánok lerakódása subepithelialisan és a keratocytákban (nyíl) 
néshez vezetnek [13]. A visszatéró cornealis eróziók incidenciája kisebb, mint LCD esetében.

Mikroszkóppal vizsgálva a depozitumok kemény cukorka alakú, eosinophil-hialinszerü anyagok, amelyek kezdetben a stroma elülső részében, majd progresszió folyamán a stroma mélyebb rétegeiben is megjelennek [1] (2. D) ábra). Masson-féle trikrómfestéssel a hialindepozitumok vörös színúek [12] (2. E) ábra).

\section{Granularis cornealis dystrophia, 2-es típus (Avellino-dystrophia, kombinált, granularis-lattice cornealis dystrophia)}

A granularis cornealis dystrophia 2-es típusában mind a granularis dystrophiára jellemző hialindepozitumok, mind a lattice dystrophiára jellemző amyloiddepozitumok megtalálhatók a cornea stromájában. Általában tizenéves korban jelentkezik. Az opacitások kicsi szürkésfehér gyứú, csillag vagy akár tüske alakú elváltozások lehetnek a stroma superficialis rétegében. Progresszió során a kicsiny pontszerú elváltozások lattice-vonalakká alakulnak. Az epithelialis-stromalis dystrophiákra jellemzően fájdalommal, epithelialis eróziókkal és látáscsökkenéssel jár [14]. Masson-féle trikrómfestéssel a hialindepozitumok vörös színúek [12]. Az amyloiddepozitumok kongóvörös festéssel, polarizációs mikroszkóp alatt vizsgálva almazöld birefringenciájú [14].

\section{Stromalis cornealis dystrophiák}

A stromalis cornealis dystrophiákban a mutációk következtében létrejövő elváltozások a cornea stromáját érintik. A legújabb IC3D-klasszifikáció alapján a csoportba tartozó dystrophiák a macularis és a Schnyder cornealis dystrophiák [15].

\section{Macularis cornealis dystrophia (MCD, Groenouw cornealis dystrophia 2-es tipus)}

A macularis cornealis dystrophia autoszomális recesszív öröklődésú betegség, amelynek kialakulása a 16. kromoszómán található CHST6 (carbohydrate-sulfotransferase 6) génnel hozható összefüggésbe. A gén mutációja a keratán-szulfát proteoglikánok szintézisének zavarához vezet [16]. A dystrophia általában fiatal életkorban jelentkezik, de akár a 6. évtizedben is kezdődhet. Kevésbé gyakori, mint az LCD és a GCD, de a macularis cornealis dystrophia esetében a látásélesség csökkenése sokkal súlyosabb [1]. Diffúz cornealis homály jellemzi, a szaruhártyán felhőszerú homályok jelennek meg. Az opacitások mind centrálisan, mind perifériásan megtalálhatók és a stroma egész vastagságát érintik. Az MCD, bár stromalis dystrophia, de érinti a Descemet-membránt és az endotheliumot is [17].
Az MCD-nek három altípusa van [18]. Az I-es és I/A altípusok esetében a páciensek szérumában és cornealis extracelluláris mátrixában nincs detektálható keratánszulfát-szint. Az MCD II-es altípusában a betegségben szenvedők szérumában a keratán-szulfát-szint normális [1].

Hisztopatológiai szempontból vizsgálva a betegséget intracitoplazmatikus anyagfelhalmozódás látható a keratocytákban és az endothelsejtekben. Ezek PAS-sal festô" dő glükózaminoglikánokat tartalmaznak [5] (2. F) ábra), valamint az ECM-ben abnormálisan szulfatált kondroitináz-ABC lelhető fel.

MCD-ben a cornealis vastagság csökkent, ennek oka hibás keratán-szulfát proteoglikán szintézis, amelynek következtében a kollagénrostok ugyan normális átmérójűek, de az interfibrillaris távolság kisebb, mint normális corneákban.

A Descemet-membrán elülső része normális vastagságú, nem figyelhető meg elváltozás, míg a hátsó rész vacuolumképződés miatt lépesmézszerú mintázatot mutat [1].

\section{Schnyder cornealis dystrophia}

A Schnyder cornealis dystrophia autoszomális domináns öröklódésű, bilateralis megjelenést mutató, stromalis cornealis dystrophia [19]. A betegség kialakulásáért az lp36 kromoszómán található UBIADl (Ubi A phenyltransferase domain containing $\mathrm{l}$ ) gén mutációja felelös [20], amely a koleszterolmetabolizmus zavarát vonja maga után. A betegség pontos patogenezise nem ismert, de feltételezések szerint az UBIADl gén olyan proteint termel, amely a koleszterolmetabolizmusban játszik szerepet [21]. A fehérje károsodása miatt krisztallindepozitumok rakódnak le a cornea stromájában [22]. A krisztallinlerakódás oka viszont ismeretlen, mert kérdéses, hogy fokozott termelődése vagy csökkent eltávolítása okozza a cornea rétegei közötti felhalmozódását. Immunhisztokémiai eljárásokkal HDL- (apo-AI, apo-AII, apo-C) lerakódás figyelhetô meg.

A dystrophia az élet első évtizedében jelentkezik, az idő folyamán lassan progrediál. A betegség diagnosztizálása nem könnyú feladat, gyakran csak a páciensek 30-as éveiben deríthető ki [21]. Ennek oka, hogy a betegek csupán 54\%-ában figyelhetôk meg a krisztallindepozitumok, ezek hiányában a diagnózis késhet [5].

Fiatal, huszonévesnél fiatalabb páciensek esetében centrális cornealis opacitás látható, ekkor a látásélesség és a cornealis érzékelés még megtartott. Késôbb, huszonéves korban úgynevezett arcus lipoides látható a szaruhártya rétegei között, a látásélesség csökken. A 39 évnél idősebb páciensek esetében az egész stromát átérő homály detektálható a látásélesség lényeges csökkenése mellett.

A hisztopatológiai diagnózis elővigyázatosságot igényel, mert a szövet fixálása során a lipidek kioldódhatnak [21]. 


\section{Következtetések}

Az öröklött cornealis dystrophiák változatos szövettani képet mutatnak a mutációk (BIGH3, CHST6, UBIADl ) következtében létrejövő különböző kóros fehérjék termelődése és azoknak a szaruhártya különböző rétegeiben való lerakódása miatt [5]. A depozitumok a stromalis extracelluláris mátrix szerkezetének megváltozásához vezetnek [4], ezáltal a szaruhártya elveszíti transzparenciáját.

Ezeken a mutációkon kívül más feltételezhető patogenezis is állhat a cornealis dystrophiák hátterében. A DEKK Szemklinikán különböző adhéziós molekuláknak tulajdonítottak szerepet a cornealis dystrophiák kialakulásában. A kutatás során az ICAM-1 (intracellular adhesion molecule 1), az E-szelektin (endothelial selectin) és az E-cadherin (endothelial cadherin) adhéziós molekulákat vizsgálták lattice, granularis és macularis cornealis dystrophiákban. Kimutatták, hogy ezek az adhéziós molekulák normális corneákban nincsenek jelen, dystrophiákban viszont gyengébb vagy fokozott expressziójuk is megfigyelhető lehet a szaruhártya epitheliumában, a Bowman-membránban, illetve a stromában [23].

$\mathrm{Az}$ epithelialis-stromalis és a stromalis dystrophiák is fiatal életkorban alakulnak ki, de csak később manifesztálódnak szaruhártya-eróziók és a látásélesség csökkenése formájában.

A betegség előrehaladott stádiumában a fokozott cornealis homály és az eróziók miatt általában keratoplasztika válik szükségessé [1], ezért a cornealis dystrophiák kutatása, patogenezisük pontos ismerete kiemelkedő jelentőségú a sebészeti terápia időbeni megválasztásában vagy esetleges elkerülésében.

\section{Anyagi támogatás: NAP_KTIA_13_NAP-A-II/7 (HT); AGR_PIAC_13-1-2013-0008.}

Szerzői munkamegosztás: A kézirat megszövegezésében, elkészítésében mind a négy szerző részt vett. A szerzők a kézirat végleges változatát elolvasták és jóváhagyták.

Érdekeltségek: A szerzőknek nincsenek érdekeltségeik.

\section{Irodalom}

[1] Klintworth, G. K.: Corneal dystrophies. OJRD, 2009, 4(1), 7 DOI: 10.1186/1750-1172-4-7. http://www.ojrd.com/content $/ 4 / 1 / 7$

[2] Módis, L. Jv., Szalai, E., Facskó, A., et al.: Corneal transplantation in Hungary (1946-2009). Clin. Experiment. Ophthalmol., $2011,39(6), 520-525$.

[3] Waring, G. O. 3rd., Rodrigues, M. M., Laibson, P. R.: Corneal dystrophies. I. Dystrophies of the epithelium, Bowman's layer and stroma. Surv. Ophthalmol., 1978, 23(2), 71-122.

[4] Varkoly, G., Bencze, J., Hortobágyi, T., et al.: The corneal wound healing and the extracellular matrix. [A cornealis sebgyógyulás és az extracelluláris mátrix.] Orv. Hetil., 2016, 157(25), 995-999. [Hungarian]
[5] Birkholz, E. S., Syed, N. A., Wagoner, M. D.: Corneal stromal dys trophies: A clinicopathologic review. EyeRounds.org, July 29, 2009. http://webeye.ophth.uiowa.edu/eyeforum/cases/43corneal-stromal-dystrophies.pdf

[6] Kocak-Altintas, A. G., Kocak-Midillioglu, I., Akarsu, A. N., et al.: BIGH3 gene analysis in the differential diagnosis of corneal dystrophies. Cornea, 2001, 20(1), 64-68.

[7] Rozzo, C., Fossarello, M., Galleri, G., et al.: A common beta ig-h3 gene mutation (delta f540) in a large cohort of Sardinian Reis Bücklers corneal dystrophy patients. Mutations in brief no. 180 . Online. Hum. Mutat., 1998, 12(3), 215-216.

[8] Kim, H. B., Park, Y. S.: Lattice corneal dystrophy. J. Korean Ophthalmol. Soc., 1980, 21(3), 317-321.

[9] Klintworth, G.: Lattice corneal dystrophy. An inherited variety of amyloidosis restricted to the cornea. Am. J. Pathol., 1967, 50(3), 371-399.

[10] Purcell, J. J. Jr., Rodrigues, M., Chishti, M. I., et al.: Lattice corneal dystrophy associated with familial systemic amyloidosis (Meretoja's syndrome). Ophthalmology, 1983, 90(12), 15121517 .

[11] Stock, E. L., Feder, R. S., O’Grady, R. B., et al.: Lattice corneal dystrophy type IIIA. Clinical and histopathologic correlations. Arch. Ophthalmol., 1991, 109(3), 354-358.

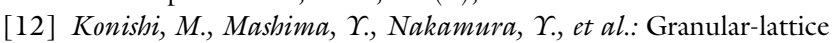
(Avellino) corneal dystrophy in Japanese patients. Cornea, 1997, 16(6), 635-638.

[13] Stewart, H. S., Ridgway, A. E., Dixon, M. J., et al.: Heterogeneity in granular corneal dystrophy: Identification of three causative mutations in the TGFBI(BIGH 3) gene - Lessons for corneal amyloidogenesis. Hum. Mutat., 1999, 14(2), 126-132.

[14] Lucarelli, M. J., Adamis, A. P.: Avellino corneal dystrophy. Arch. Ophthalmol., 1994, 112(3), 418-419.

[15] Nowinska, A.: Stromal corneal dystrophies. Acta Ophthalmol., 2014, 92(Suppl.), S253.

[16] Kaarniranta, K., Szalai, E., Smedowski, A., et al.: A novel proteotoxic stress associated mechanism for macular corneal dystrophy. Histol. Histopathol., 2015, 30(8), 921-930.

[17] Hassell, J. R., Newsome, D. A., Krachmer, J. H., et al.: Macular corneal dystrophy: failure to synthesize a mature keratan sulfate proteoglycan. Proc. Natl. Acad. Sci. U.S.A., 1980, 77(6), 37053709.

[18] Vance, J. M., Jonasson, F., Lennon, F., et al.: Linkage of a gene for macular corneal dystrophy to chromosome 16. Am. J. Hum. Genet., 1996, 58(4), 757-762.

[19] Ingraham, H. J., Perry, H. D., Donnenfeld, E. D., et al.: Progressive Schnyder's corneal dystrophy. Ophthalmology, 1993, 100(12), 1824-1827.

[20] Nickerson, M. L., Kostiha, B. N., Brandt, W., et al.: UBIADI mutation alters a mitochondrial prenyltransferase to cause Schnyder corneal dystrophy. PLoS ONE, 2010, 5(5), el0760.

[21] Weiss, J. S.: Schnyder corneal dystrophy. Curr. Opin. Ophthalmol., 2009, 20(4), 292-298.

[22] Weiss, J. S., Rodrigues, M. M., Kruth, H. S., et al.: Panstromal Schnyder's corneal dystrophy: ultrastructural and histochemical studies. Ophthalmology, 1992, 99(7), 1072-1081.

[23] Nemeth, G., Felszeghy, Sz., Kenyeres, A., et al.: Cell adhesion molecules in stromal corneal dystrophies. Histol. Histopathol., $2008,23(8), 945-952$.

(Hortobágyi Tibor dr., Debrecen, Nagyerdei krt. 98., 4032 e-mail: hortobagyi@med.unideb.hu)

(Módis László dr., Debrecen, Nagyerdei krt. 98., 4032 e-mail: modis.laszlo@med.unideb.hu) 